\title{
Reply to Häuser et al.
}

Citation for published version (APA):

Treede, R-D., Rief, W., Korwisi, B., Perrot, S., Cohen, M., Nicholas, M., Vlaeyen, J. W. S., \& Barke, A. (2019). Reply to Häuser et al. Fibromyalgia as a chronic primary pain syndrome : issues to discuss. Pain, 160(11), 2652-2653. https://doi.org/10.1097/j.pain.0000000000001687

Document status and date:

Published: 01/11/2019

DOI:

10.1097/j.pain.0000000000001687

Document Version:

Publisher's PDF, also known as Version of record

\section{Document license:}

Taverne

\section{Please check the document version of this publication:}

- A submitted manuscript is the version of the article upon submission and before peer-review. There can be important differences between the submitted version and the official published version of record.

People interested in the research are advised to contact the author for the final version of the publication, or visit the DOI to the publisher's website.

- The final author version and the galley proof are versions of the publication after peer review.

- The final published version features the final layout of the paper including the volume, issue and page numbers.

Link to publication

\footnotetext{
General rights rights.

- You may freely distribute the URL identifying the publication in the public portal. please follow below link for the End User Agreement:

www.umlib.nl/taverne-license

Take down policy

If you believe that this document breaches copyright please contact us at:

repository@maastrichtuniversity.nl

providing details and we will investigate your claim.
}

Copyright and moral rights for the publications made accessible in the public portal are retained by the authors and/or other copyright owners and it is a condition of accessing publications that users recognise and abide by the legal requirements associated with these

- Users may download and print one copy of any publication from the public portal for the purpose of private study or research.

- You may not further distribute the material or use it for any profit-making activity or commercial gain

If the publication is distributed under the terms of Article $25 \mathrm{fa}$ of the Dutch Copyright Act, indicated by the "Taverne" license above, 
a symptom or a disease: the IASP classification of chronic pain for the International Classification of Diseases (ICD-11). PAIN 2019;160:19-27.

[8] Wolfe F, Häuser W, Hassett AL, Katz RS, Walitt BT. The development of fibromyalgia-l: examination of rates and predictors in patients with rheumatoid arthritis (RA). PAIN 2011;152:291-9

$\begin{array}{r}\text { Winfried Häuser }{ }^{\mathbf{a}} \\ \text { Daniel Clauw }{ }^{\mathbf{b}}\end{array}$
Mary-Ann Fitzcharles ${ }^{\mathbf{c}}$
aDepartment Psychosomatic Medicine and Psychotherapy,
Technische Universität München,
München,
Germany and Health Care Center for
Pain Medicine and Mental Health,
Saarbrücken, Germany
bepartments of Anesthesiology,
Medicine and Psychiatry,
The University of Michigan,
Ann Arbor,
MI, United States
${ }^{c}$ Alan Edwards Pain Management Unit,
Division of Rheumatology,
McGill University Health Centre,
QC, Canada
E-mail address: mary-ann.fitzcharles@muhc.mcgill.ca (M.-A.
Fitzcharles)
http://dx.doi.org/10.1097/j.pain.0ooooooooooo1686

\section{Reply to Häuser et al.}

\section{Letter to Editor:}

We appreciate the thoughtful comments of Häuser et al. ${ }^{2}$ on the new classification of chronic pain conditions that has been suggested by the IASP task force on $/ C D-11^{6}$ and that has been adopted by the World Health Assembly in May 2019. ${ }^{7}$ Häuser et al. $^{2}$ discuss some potential implications of classifying fibromyalgia syndrome as chronic primary pain syndrome instead of musculoskeletal disease. We agree that the points they raise are worth a discussion, and we think that some answers can already be given now, including the responses here:

1. "Chronic primary pain" applies to chronic pain syndromes that are best conceived as health conditions in their own right, where pain is the leading complaint that cannot be better accounted for by another chronic (secondary) pain condition. ${ }^{3}$ Fibromyalgia, complex regional pain syndromes, and primary headaches or orofacial pain fall under this heading, as well as chronic primary visceral pain and chronic primary musculoskeletal pain. We consider that this approach in fact transcends the view of fibromyalgia as "musculoskeletal disease," especially as Häuser et al. ${ }^{2}$ make the points that "FMS [fibromyalgia syndrome] is a heterogeneous condition" which has "defied clear definition." The concept of "chronic primary pain" not only embraces such clinical complexity but also invites a broader consideration of the role of altered nociceptive function.

2. Fibromyalgia is a child category of "chronic widespread pain" because widespread pain is one of its prerequisites in the previous definitions and clinical descriptions. By contrast, "chronic primary musculoskeletal pain" is limited to one region (cervical, thoracic, low back, or limbs). ${ }^{3}$ Multisite musculoskeletal pain as mentioned by Häuser et al. $^{2}$ would fall under chronic widespread pain.

3. Häuser et al. ${ }^{2}$ contend that the definition of "significant" emotional distress and/or functional disability is not clarified in our account of chronic primary pain. In fact, we made several references to the concept of severity. Specifically, we referred to "significant emotional distress (eg, anxiety, anger, frustration, or depressed mood) and/or significant functional disability (interference in activities of daily life and participation in social roles). ${ }^{4}$ In other words, the experience of chronic pain should be sufficiently concerning for the person to seek help for it."3

Our position is analogous to the approach taken in several DSM-5 diagnoses, such as major depressive disorder where a required criterion is "The symptoms cause clinically significant distress or impairment in social, occupational, or other important areas of functioning."1 Similarly, in chronic primary pain, if the degree of distress or functional disability is not significant, then simply, the criteria for the diagnosis are not met. That does not mean the person concerned does not have pain, just not sufficient features to meet the criteria for a diagnosis of chronic primary pain (just as you can have depressed feelings but not meet criteria for the diagnosis of major depression). This is an important basis for identifying samples for research and clinical decision-making.

4. We maintain the position that chronic widespread pain should not be diagnosed when pain can be directly attributed to nociceptive or neuropathic processes in the painful regions. According to current knowledge, nociceptive or neuropathic mechanisms would indicate other pain disorders, while the etiology of fibromyalgia syndrome is typically unclear. With the new definition, we explicitly neither preclude somatic contributors nor require psychological ones. In our view, this best reflects the current state of the evidence. So, nociceptive or neuropathic factors are compatible with the definition-but they should not fully account for the condition. If they did, the chronic pain would be classified as an inflammatory musculoskeletal condition in the section of secondary musculoskeletal pain. ${ }^{5}$

5. We did not explicitly address the topic of comorbid or "secondary" fibromyalgia. But, this issue can be solved by giving 2 codes for such patients; this is explicitly encouraged under ICD-11. These codes could be fibromyalgia and an organ-related code such as inflammatory rheumatic disease, or they could include 2 different pain codes, if the patient exhibits more than one type of chronic pain. It will be useful to analyze case reports of such patients for classification and then follow-up on management and further development.

We hope that this published correspondence will contribute to an ongoing discussion within the pain, rheumatology, and mental health communities for a better understanding of the relationship between chronic primary pain and fibromyalgia as a subset of that category.

\section{Conflict of interest statement}

A. Barke reports personal fees from the International Association for the Study of Pain, outside the submitted work. B. Korwisi reports personal fees from the International Association for the Study of Pain, during the conduct of the study. R.-D. Treede reports grants from Boehringer Ingelheim, Astellas, AbbVie, and Bayer, personal fees from Astellas, Grünenthal, Bauerfeind, Hydra, Glaxo-Smith-Kline, and Bayer, and grants from EU, DFG, and BMBF, outside the submitted work.

\section{References}

[1] American Psychiatric Association. Diagnostic and statistical manual of mental disorders: DMS-5. Washington, DC: APA, 2013.

[2] Häuser W, Clauw D, Fitzcharles MA. Fibromyalgia syndrome as a primary chronic pain syndrome: issues to discuss. PAIN 2019;160:2651-2. 
[3] Nicholas M, Vlaeyen JWS, Rief W, Barke A, Aziz Q, Benoliel R, Cohen M, Evers S, Giamberardino MA, Göbel A, Korwisi B, Perrot S, Svensson P, Wang SJ, Treede RD; The IASP Taskforce for the Classification of Chronic Pain. The IASP classification of chronic pain for ICD-11: chronic primary pain. PAIN 2019;160:28-37.

[4] Nugraha B, Gutenbrunner C, Barke A, Karst M, Schiller J, Schäfer P, Falter S, Korwisi B, Rief W, Treede RD; The IASP Taskforce for the Classification of Chronic Pain. The IASP classification of chronic pain for ICD-11: functioning properties of chronic pain. PAIN 2019;160:88-94.

[5] Perrot S, Cohen M, Barke A, Korwisi B, Rief W, Treede RD; The IASP Taskforce for the Classification of Chronic Pain. The IASP classification of chronic pain for ICD-11: chronic secondary musculoskeletal pain. PAIN 2019;160:77-82.

[6] Treede RD, Rief W, Barke A, Aziz Q, Bennett MI, Benoliel R, Cohen M, Evers S, Finnerup NB, First MB, Giamberardino MA, Kaasa S, Korwisi B, Kosek E, Lavand'homme P, Nicholas M, Perrot S, Scholz J, Schug S, Smith BH, Svensson P, Vlaeyen JWS, Wang SJ. Chronic pain as a symptom and a disease: the IASP classification of chronic pain for the international classification of diseases ICD-11. PAIN 2019;160:19-27.

[7] World Health Organization. ICD-11 International Classification of Diseases for Mortality and Morbidity Statistics. Eleventh Revision. Reference Guide. Geneva: WHO, 2019. Available at: https://icd. who.int/icd11refguide/en/index.html. Accessed February 18, 2019.

\section{Rolf-Detlef Treede ${ }^{a}$ Winfried Rief ${ }^{\text {b }}$ Beatrice Korwisi ${ }^{b}$ Serge Perrot ${ }^{c}$ Milton Cohen ${ }^{d}$ Michael Nicholas ${ }^{e}$ Johan W. S. Vlaeyen ${ }^{\mathrm{f}, \mathrm{g}, \mathrm{h}}$ Antonia Barke ${ }^{\mathrm{b}, \mathrm{i}}$ ${ }^{a}$ Neurophysiology,} Center for Biomedicine and Medical Technology Mannheim (CBTM),
Medical Faculty Mannheim of Heidelberg University,

Mannheim, Germany

${ }^{b}$ Department of Clinical Psychology and Psychotherapy, Marburg University, Marburg, Germany

${ }^{c}$ Pain Clinic, Cochin Hospital, Paris Descartes University, INSERM U 987,

Paris, France

'St Vincent's Clinical School, UNSW Sydney,

Sydney, New South Wales, Australia ePain Management Research Institute,

Royal North Shore Hospital, University of Sydney, Sydney, Australia

${ }^{f}$ Research Group Health Psychology, University of Leuven, Leuven, Belgium ${ }^{9}$ Department of Clinical Psychological Science, Maastricht University, Maastricht, The Netherlands

${ }^{n}$ TRACE,

Center for Translational Health Research, KU, Leuven-Ziekenhuis Oost-Limburg, Genk, Belgium

'Catholic University of Eichstätt-Ingolstadt, Clinical and Biological Psychology, Eichstätt, Germany

E-mail address: Rolf-Detlef.Treede@medma.uni-heidelberg.de (R.-D. Treede) http://dx.doi.org/10.1097/j.pain.0000000000001687 